\title{
A Checklist of Books and Articles in the Field of the History of the Book and Libraries, Part 1
}

\author{
Liana Van der Bellen
}

THE BIBLIOGRAPHICAL SOCIETY OF CANADA HAS UNDERTAKEN TO PUBLISH IN several instalments the Canadian entries sent over the years to the Annual Bibliography of the History of the Printed Book and Libraries ( $A B H B)$. The $A B H B$ has been issued yearly since I970. It is published under the auspices of the Committee on Rare and Precious Books and Documents of the International Federation of Library Associations (IFLA) and edited by Hendrik D.L. Vervliet in Antwerp. National Committees in twenty-five countries send bibliographical data on each year's publications in the field to the editorial office. Canadian entries have been included since volume 5 (1975) and have been gathered and sent by Miss M.E. Brown of the University of Toronto Library and after her retirement by Miss L. Van der Bellen of the National Library of Canada and Mr. Peter Greig, now of the National Defence Library in Ottawa. While delays were experienced during the first few years of the $A B H B$, automation has speeded up the publication process. Thus the volume listing I982 publications came out in 1984. The $A B H B$ includes the history of printing, typography, publishing, the book trade, illustration, binding, paper-making, book collecting, libraries and librarianship, newspapers and journalism, as well as retrospective bibliography and bibliographical studies. The emphasis is on historical content and scholarly treatment of the topics.

For publication in the BSC Papers / Cahiers, some modifications have been made in the bibliographic style and headings, as well as content; some items originally omitted from the $A B H B$ because they did not meet its criteria have been included, such as articles and books on contemporary book arts, and non-Canadian topics have been omitted. Short annotations have been included in brackets after titles which are not self-explanatory. The listings begin with I970 and include articles which originally appeared in the вsC Papers / Cahiers. The first part of the Checklist, published here, includes publications in the areas of the history of the book and printing, publishing and the book trade, modern fine printing, small and private presses and livres d'artistes. In subsequent issues other topics covered by the $A B H B$ will be listed. 
We hope that these lists will be of interest to the members of the Society, and we would be happy to receive notice of items which have been missed.

History of the Book and Printing

Banks, Joyce M. 'The Church Missionary Society Press at Moose Factory: I 853-I 859.' Journal of the Canadian Church Historical Society 26, no. 2 (I984): 69-80.

Banks, Joyce M. 'The Printing of the Cree Bible.' Papers of the Bibliographical Society of Canada / Cahiers de la Société bibliographique du Canada 22 (I983): I2-29.

Bibliothèque nationale du Québec. Le livre québécois, 1764-1972. Montreal: Ministère des Affaires culturelles, I972. I68 p. [Catalogue d'exposition]

Books in Canada, Past and Present: An Exhibition / Livres canadiens d'hier et d'aujourd'hui: une exposition. Ottawa: National Library of Canada / Bibliothèque nationale du Canada, r982. 34 p.

Buono, Yolande. 'Imprimerie et diffusion de l'imprimé à Montréal, I 776I 820.' Thèse de maîtrise (bibliothéconomie), Université de Montréal, I980. V, 2 I 6 p.

Buono, Yolande. 'Imprimerie et diffusion de l'imprimé à Montréal, I776I 820.' Documentation et bibliothèques 28, no. I (I 982): I 5-25.

'CP \& P Hits 90 Year Mark.' Canadian Printer «) Publisher 91, no. 5 (I982): 8.

Carroll, E.G. 'History of Printing (Prince Edward Island).' Canadian Antiques Collector 8, no. I (I973): 43-45.

Chappell, W.G. 'Commentary on the Shorthand Used in the Kamloops Wawa.' Amphora 20, no. 2 (I975): 8-10.

Chard, Donald F. 'Bushell (Bushel), John, Printer.' In Dictionary of Canadian Biography, vol. 3, 90-9I. Toronto: University of Toronto Press, I974. Version française: Dictionnaire biographique du Canada, vol. 3, 96-97. Quebec: Les Presses de l'Université Laval, I 974.

Chard, Donald F. 'Green, Bartholomew, Printer.' In Dictionary of Canadian Biography, vol. 3, 267. Toronto: University of Toronto Press, 1974. Version française: Dictionnaire biographique du Canada, vol. 3, 286-287. Quebec: Les Presses de 1'Université Laval, I974.

Chassé, Béatrice. 'Collection Neilson.' Rapport de l'Archiviste de la Province de Québec 52 (1974): 25-37.

Dawson, R. MacG. 'A Seventeenth-Century Replica Printing Press.' The Devil's Artisan: A Journal of the Printing Arts 7-8 (I982): 8-I6; 8-I3.

Desrochers, Luc. 'Les facteurs d'apparition du syndicalisme catholique dans l'imprimerie et les déterminants de la stratégie syndicale, I 92 II945.' Revue d'histoire de l'Amérique française 37 (I983): 24 I-269. 
Devost, Alain. L'imprimerie au Québec: son historique, ses aspects socio-économiques, ses techniques, les risques pour la santé et la sécurité, la prévention de ces risques. Quebec: Commission de la santé et la sécurité du travail, I982. 366 p.

Duverdier, Gérald. 'Les imprimeries néo-européennes.' Revue française d'histoire du livre n.s. I6 (I977): 503-530.

Elliott, Shirley B. 'Fletcher, Robert, Printer and Merchant.' In Dictionary of Canadian Biography, vol. 4, 267. Toronto: University of Toronto Press, I979. Version française: Dictionnaire biographique du Canada, vol. 4, 288. Quebec: Les Presses de 1’Université Laval, I980.

Elliott, Shirley B. 'Heritage in Printing.' Canadian Collector 7 , no. I (I972): 7 I-74. [Printing in Nova Scotia]

L'évolution du rôle social de l'imprimé et de ses agents au Québec: texte intégral des conférences présentées lors de la série 1979-1980 des Conférences Aegidius-Fauteux. Montreal: Les Conférences AegidiusFauteux, I98I. 78 p.

Firth, Edith G. 'Books and Broadsides.' In The Book of Canadian Antiques, edited by Donald Blake Webster, 3 I3-326. Toronto: McGraw-Hill Ryerson, I974.

Fleming, Patricia Lockhart. 'A Canadian Printer's Apprentice in I826.' The Devil's Artisan: A Journal of the Printing Arts 9(I982): I 3-I7.

Fleming, Patricia Lockhart. 'The Printing Trade in Toronto: I798-I84I.' In Sticks and Stones: Some Aspects of Canadian Printing History, 47-68. Toronto: Toronto Typographic Association, I980.

Fleming, Patricia Lockhart. 'William Lyon Mackenzie as Printer, I824I837.' The Devil's Artisan: A Journal of the Printing Arts 5-6 (I98 I): 3I 2; 3-I9.

Gagnon, Jean. 'Un minuscule canadien.' Cahiers de bibliologie I (I980): 29-30

Gagnon, Jean. 'Notes sur un mandement de Monseigneur de Pontbriand daté du 28 octobre, I759.' Cahiers de bibliologie I (I980): 25-28.

Galarneau, Claude. 'Le livre ancien au Québec: état présent des recherches.' Revue française d'histoire du livre I6 (I977): 335-348.

Galarneau, Claude. 'Livre et société à Québec (I 760-I 859): état des recherches.' In L'imprimé au Québec: aspects historiques (18e-2oe siècles), I 29-I44. Quebec: Institut québécois de recherche sur la culture, I983.

Galarneau, Claude. 'Mesplet, Fleury, imprimeur, éditeur et libraire.' In Dictionnaire biographique du Canada, vol. 4, 575-578. Quebec: Les Presses de 1'Université Laval, I980. English version: Dictionary of Canadian Biography, vol.4, 532-535. Toronto: University of Toronto Press, I979. 
Galarneau, Claude. 'Les métiers du livre à Québec (I764-I859).' Les cahiers des dix no. 43 (1983): I43-I65.

Gallichan, Gilles. 'Histoire du livre et informatique: 1'expérience du PACPAQ.' Bulletin de la Bibliothèque de l'Assemblée nationale du Québec I4, no. 3 (1984): 3-гo.

Gauvin, Daniel. 'Thomas Cary et le monde de l'imprimé à Québec au début du xıxe siècle.' Les cahiers du livre ancien du Canada français I, no. I (I984): 32-35.

Gervais, Jean-François. 'Brown, William, journaliste et imprimeur.' In Dictionnaire biographique du Canada, vol. 4, I I4-I I6. Quebec: Les Presses de 1'Université Laval, I980. English version: Dictionary of Canadian Biography, vol. 4, I05-107. Toronto: University of Toronto Press, I979.

Gervais, Jean-François. 'Gilmore (Gilmour), Thomas, journaliste, imprimeur.' In Dictionnaire biographique du Canada, vol. 4, 3 I7-3 I 8. Quebec: Les Presses de 1'Université Laval, I980. English version:

Dictionary of Canadian Biography, vol. 4, 294-295. Toronto:

University of Toronto Press, I979.

Gibson, John and Laurie Lewis, comp. Sticks and Stones: Some Aspects of Canadian Printing History. Toronto: Toronto Typographic Association, I980. I 2op.

Greig, Peter. 'A Checklist of Primary Source Material Relating to Fleury Mesplet.' Papers of the Bibliographical Society of Canada / Cahiers de la Société bibliographique du Canada I 3 (I974): 49-74.

Greig, Peter. 'Fleury Mesplet (I734-I794), the First French Printer in the Dominion of Canada: A Bibliograhical Discussion.' Master's thesis, School of English, University of Leeds, I974. iii, 2 I 41.

Gundy, H. Pearson. The Spread of Printing: Western Hemisphere. Canada. Amsterdam: Van Gendt; London: Routledge \& Kegan Paul; New York: Abner Schram, I972.86 p.

Hare, John E. 'Neilson, Samuel, imprimeur.' In Dictionnaire biographique du Canada, vol. 4, 628-629. Quebec: Les Presses de 1'Université Laval, I979. English version: Dictionary of Canadian Biography, vol. 4, 58058 I. Toronto: University of Toronto Press, r980.

Hare, John E. 'Roy, Louis, imprimeur.' In Dictionnaire biographique du Canada, vol. 4, 746-748. Quebec: Les Presses de l'Université Laval, I980. English version: Dictionary of Canadian Biography, vol. 4, 689690. Toronto: University of Toronto Press, I 979.

Hare, John E., et Jean-Pierre Wallot. 'Les imprimés au Québec (I $760-$ I820).' In L'imprimé au Québec: aspects historiques (18e-20e siècles), 79-I 25. Québec: Institut québécois de recherche sur la culture, I983. Harper, J. Russell. 'Sower (Sauer, Saur), Christopher, Printer and Office- 
Holder.' In Dictionary of Canadian Biography, vol. 4, 72 I-722. Toronto: University of Toronto Press, 1979. Version française: Dictionnaire biographique du Canada, vol. 4, 782-783. Quebec: Les Presses de 1'Université Laval, I980.

Hulse, Elizabeth. A Dictionary of Toronto Printers, Publishers, Booksellers and the Allied Trades, 1798-1900. Toronto: AnsonCartwright Editions, I982. 336 p.

Hulse, Elizabeth. 'An Early Canadian Type Specimen Book.' The Devil's Artisan: A Journal of the Printing Arts 4 (I98I): I2-I8.

Labrie, Vivian. 'L'imprimé et les traditions orales: réflexion sur le problème et exemple de méthode.' In L'imprimé au Québec: aspects historiques (18e-20e siècles), 55-76. Quebec: Institut québécois de recherche sur la culture, I983.

Lamonde, Yvan. 'Bilan de la recherche sur l'histoire de l'imprimé et du livre québécois, faisant ressortir les secteurs où le travail de recherche est à peine amorcé ou entièrement à effectuer.' Revue d'histoire de l'Amérique française 28 (I974): 405-4I4.

Lamonde, Yvan, éd. L'imprimé au Québec: aspects historiques $118 e-20 e$ siècles). Culture savante, no. 2. Quebec: Institut québécois de recherche sur la culture, I983. $386 \mathrm{p}$.

Lamonde, Yvan. 'La recherche récente en histoire de l'imprimé au Québec.' In L'imprimé au Québec: aspects historiques (18e-20e siècles), I I-24. Quebec: Institute québécois de recherche sur la culture, I983.

Landon, Richard. 'The History of the Book in Canada and British Research Resources.' In Canadian Studies: Papers Presented at a Colloquium at the British Library, 1983, edited by Patricia McLaren-Turner, I 87-I88. London: The British Library, I984.

Leduc, Jean. 'Le livre matériel de poésie au Québec, I950-I970.' Thèse de maîtrise (bibliothéconomie), Université de Montréal, I980. iii, I69 p.

Leduc, Jean. 'Le livre matériel de poésie au Québec de I950 à I970.' Documentation et bibliothèques 29, no. 3 (I982): 105-I09.

Lemay, Thérèse P. 'Joe, esclave noir, pressier.' In Dictionnaire biographique du Canada, vol. 4, 423-424. Quebec: Les Presses de 1'Université Laval, I980. English version: Dictionary of Canadian Biography, vol. 4, 392-393. Toronto: University of Toronto Press, I979.

Livre, bibliothèque et culture québécoise: mélanges offerts à Edmond Desrochers, s.j., 2 vols. Montreal: AsTED, 1977.

'Le livre-texte.' Etudes françaises I 8, no. 3 (I983): 3-I29. [Numéro spécial sur le livre de la revue Etudes françaises]

Lochhead, Douglas G. 'Henry, Anthony (also Anton Heinrich or Henrich) Printer and Publisher.' In Dictionary of Canadian Biography, vol. 4, 342-343. Toronto: University of Toronto Press, I979. Version française: 
Dictionnaire biographique du Canada, vol. 4, 369-370. Quebec: Les Presses de l'Université Laval, I980.

Lovell \& Gibson. Specimen of Printing Types and Ornaments in Use at the Printing Office of Lovell « Gibson, St. Nicholas Street, Montreal (1846). Bibliographical Society of Canada / Société bibliographique du Canada, Facsimile Series, no. 9. Toronto: Bibliographical Society of Canada / Société bibliographique du Canada, I975. 235 p.

McDonald, Rod. 'Cartier Revisited.' The Devil's Artisan: A Journal of the Printing Arts I 3 (I984): 4-8.

The Natural History of the Book, Parts I-III. Toronto: СвС Transcripts, I982. 3 I, v p. [Transcript of the Canadian Broadcasting Company programme 'Ideas,' Dec. 2-I6, I982]

Nicaise, Jean-Pierre. 'La vie aventureuse, endettée et libertaire de Fleury Mesplet, fondateur de la Gazette.' Perspectives I 8 (4 sept. I976): I2-I 5.

'L'objet-livre.' Etudes françaises I 8, no. 2 (automne I982): 3-I04. [Numéro spécial de la revue Etudes françaises]

Peel, Bruce. Early Printing in the Red River Settlement, 1859-1870, and Its Effect on the Riel Rebellion. Winnipeg: Peguis Publishers, I974. 56 p.

Peel, Bruce. 'Red River Broadsides, I869-70.' Amphora I9 (I975): 6-I 2.

Peel, Bruce. Rossville Mission Press: The Invention of the Cree Syllabic Characters, and the First Printing in Rupert's Land. Montreal: Osiris, I974. $47 \mathrm{p}$.

Poff, Douglas. 'Carl Dair and the Cartier Type Face.' In Sticks and Stones: Some Aspects of Canadian Printing History, 25-46. Toronto: Toronto Typographic Association, I980.

Robertson, Marion. 'The Loyalist Printers: James and Alexander Robertson.' Nova Scotia Historical Review 3, no. I (I983): 83-93.

Rodwell, Lloyd. 'Printing (Saskatchewan).' Canadian Antiques Collector 8, no. 4 (I973): I7-I 8.

Rueter, Marilyn. 'The Private Press in Canada: A Brief Survey.' In Sticks and Stones: Some Aspects of Canadian Printing History, 93-I I4.

Toronto: Toronto Typographic Association, I980.

Ryder, Dorothy. 'Moore, William, Actor, Printer and Journalist.' In Dictionary of Canadian Biography, vol. 4, 556-5 58. Toronto: University of Toronto Press, I979. Version française: Dictionnaire biographique du Canada, vol. 4, 6or-603. Quebec: Les Presses de 1'Université Laval, I980.

Taubert, Sigfried. 'The First German Printers in Canada.' In GermanCanadian Yearbook, 7I-75. Toronto: Historical Society of Mecklenburg, Upper Canada, I973.

Thériault, Michel. 'Fleury Mesplet (I 734-I 774), "Printer to the Congress in Montreal".' Le maître imprimeur 40, no. Io (I976): 9-I I.

Thériault, Michel. 'Fleury Mesplet, "Printer to the Congress in Montreal": 
premier imprimeur et fondateur de The Gazette à Montréal.' Forces 43 (I978): 45-5 I.

Thériault, Michel. 'Un imprimé en caractères grecs à Montréal en I837: étude d'histoire typographique.' Papers of the Bibliographical Society of Canada / Cahiers de la Société bibliographique du Canada I 3 (I974): 75-84.

Vlach, Milada. 'Premiers imprimés québécois et livres anciens.' Bulletin de la Bibliothèque nationale du Québec 7, no. 2 (1973): I-3.

Wallace, C.M. 'Lewis, William, Printer and Journalist.' In Dictionary of Canadian Biography, vol. 4, 482-483. Toronto: University of Toronto Press, I979. Version française: Dictionnaire biographique du Canada, vol. 4, 52 I-522. Quebec: Les Presses de 1'Université Laval, I980.

Wolfe, Patrick. 'Tramp Printer Extraordinary: British Columbia's John "Truth" Houston.' BC Studies 40 (Winter I978/79): 5-3 I.

Zerker, Sally F. 'George Brown and the Printer's Union.' Journal of Canadian Studies / Revue d'études canadiennes io (1975): 42-48.

Zerker, Sally F. The Rise and Fall of the Toronto Typographical Union, 1832-1972: A Case Study of Foreign Trade Union Domination.

Toronto: University of Toronto Press, I98 I. viii, 397 p.

Zilm, Glennis. 'Printing Technology in B.C. in the I 8oos.' Amphora $5 \mathrm{I}$ (I983): 3-I I.

\section{Publishing and the Book Trade}

Armour, Drew. 'Venerable Bibliophile: The Late Bernard Amtmann.' Canadian Antiques and Art Review 2 (Nov. r980): 27-29.

Association of Canadian Publishers: A History, 1970-1978. Ottawa: The Association, I978. 32 p.

Audley, Paul. 'Book Publishing in Canada.' In Getting It Back: A Program for Canadian Independence, edited by Abraham Rotstein and Gary Lax, 20I-22 I. Toronto: Clarke, Irwin, I974.

Beaulieu, Michel. 'Miron, the Publisher-Poet.' Quill ↔ Quire 45, no. I 3 (I979): 8.

Bellefeuille, Pierre de. La bataille du livre au Québec: oui à la culture française, non au colonialisme culturel. Montreal: Lémeac, I972. I37p. [Problèmes de l'édition et de la librairie au Québec, I960-I972]

Benson, Lillian Rea. 'The Illustrated Historical Atlases of Ontario with Special Reference to H. Belden \& Co.' In Aspects of Nineteenth Century Ontario, Essays Presented to James J. Talman, 267-277. Toronto:

University of Toronto Press, I974.

Bibliothèque nationale du Québec. L'Hexagone 25: rétrospective, 19531978. Montreal: Bibliothèque nationale du Québec, I979. 55 p.

Bowen, C.G. 'The Historical Context of the University Press in America.' Scholarly Publishing 2 (I97 I): 329-349. 
Bringhurst, Robert, comp. Ocean, Paper, Stone: The Catalogue of an Exhibition of Printed Objects Which Chronicle More Than a Century of Literary Publishing in British Columbia. Vancouver: William Hoffer, I984. I i2p.

Brodie, Alexander H. 'Subscription Publishing and the Booktrade in the Eighties: The Invasion of Ontario.' Studies in Canadian Literature, 2 (Winter I977): 95-Ior.

Broten, Delores, and Peter Birdsall. Paper Phoenix: A History of Book Publishing in English Canada. Victoria, B.C.: CANLIT, I980. 84 p.

Broten, Delores, and Peter Birdsall. Studies in the Book Trade. Victoria, B.C.: CANLIT, I980. $30 \mathrm{p}$.

Brummelen, Harro van. 'Shifting Perspectives: Early British Columbia Textbooks from I 872 to I925.' B.C. Studies 6o (Winter I 983-84): 3-27.

Brunet, Manon. 'Documents pour une histoire de l'édition au Québec avant I900.' Thèse de maîtrise (Etudes françaises), Université de Montréal, I979. ix, 278 p.

Calderisi, Maria. 'Music Publishing in Canada: I800-I867.' Master's thesis, McGill University, I976. I29 1.

Calderisi, Maria. Music Publishing in the Canadas, 1800-1867 / L'édition musicale au Canada, 1800-1867. Ottawa: National Library of Canada / Bibliothèque nationale du Canada, I98 r. x, I28, x, I24 p.

Calderisi, Maria. 'Sheet music publishing in the Canadas.' In Bibliographical Society of Canada Colloquium III / Société bibliographique du Canada, III[e] colloque, 1978, I I 5-I 3 I. Toronto: The Coach House Press, I979.

Cameron, Elspeth. 'Adventures in the Book Trade.' Saturday Night 98, no. I I (Nov. I983): 27-45. [Jack McClelland]

Canada. Statistics Canada. Culture Statistics, Book Publishing, a Cultural Analysis / Statistiques de la culture, édition du livre, une analyse culturelle, 1975-. Ottawa: Statistics Canada / Statistique Canada, I978- Annual / annuel.

Canada. Statistics Canada. Culture Statistics, Book Publishing, a Financial Analysis / Statistiques de la culture, édition du livre, une analyse financière, 1975/1977, 1978-1981. Ottawa: Statistics Canada / Statistique Canada, I980-1984. 2 vols.

Canada. Statistics Canada. Culture Statistics, Book Publishing, an Industry Analysis / Statistiques de la culture, édition du livre, une analyse de l'industrie, 1975-. Ottawa: Statistics Canada / Statistique Canada, I978- Annual / annuel.

Canada. Statistics Canada. Culture Statistics, Book Publishing, Textbooks / Statistiques de la culture, édition du livre, le manuel scolaire, 19751976. Ottawa: Statistics Canada / Statistique Canada, I978-I979. 2 vols. 
Cau, Ignace. L'édition du Québec de 1960 à 1977. Collection Civilisation du Québec. Quebec: Ministère des Affaires culturelles, I98 I. 202 p.

Chalifoux, Jean-Pierre. 'L'édition au Québec, I940-I950.' Thèse de maîtrise (bibliothéconomie), Université de Montréal, I973. I05 p.

Chantigny, Louis. 'Bernard Valiquette aura été un solitaire jusqu'à la toute fin.' Bulletin de la Bibliothèque nationale du Québec I7, no. I (I983); IO-I4.

Chartrand, Maurice. 'Carrière de Pierre l'Espérance, président de sogIDES limité, une des maisons importantes au Québec: évolution et progression de cette entreprise.' Commerce 75 (I 973): 25-3 I.

Chartrand, Maurice. 'Jacques Hébert, président et directeur général, Editions du Jour.' Commerce 73 (I97 I): 30-32.

Chernofsky, Jacob L. 'Bernard Amtmann, I907-I979: Memorial Tribute.' Antiquarian Bookman's Weekly 63 (I979): 3458-348I.

Corman, Linda Wilson. 'James Campbell and the Ontario Education Department, I 858-1884,' Papers of the Bibliographical Society of Canada / Cahiers de la Société bibliographique du Canada I4 (r975): I7-52. [Textbook Publishing; Édition de manuels scolaires]

Cross, Michael. 'Derbishire, Stewart, Public Official.' In Dictionary of Canadian Biography, vol. 9, 2O -202. Toronto: University of Toronto Press, 1976. Version française: Dictionnaire biographique du Canada, vol. 9, 22 I-222. Quebec: Les Presses de 1'Université Laval, I977.

[Queen's Printer]

Curtis, Bruce. 'Schoolbooks and the Myth of Curricular Republicanism: The State and Curriculum in Canada West, I820-I850.' Social History / Histoire sociale I6 (I983): 38 I-4 IO.

Desbarats, Aileen. 'Desbarats, George-Paschal, Printer, Publisher and Businessman.' In Dictionary of Canadian Biography, vol. 9, 202-203. Toronto: University of Toronto Press, I976. Version française: Dictionnaire biographique du Canada, vol. 9, 222-223. Quebec: Les Presses de l'Université Laval, I977.

Ettlinger, John R.T., ed. Publishing in Canada II: East Looks West. Halifax: Dalhousie University School of Library Service, I973. I 2 p. Fleming, Patricia Lockhart. 'A History of Publishing in Toronto, I798 to I 84 I, with a Descriptive Bibliography of Imprints.' Ph.D. thesis, University of London, I980. 79 I p.

Gagnon, Jean. 'Les livres de récompense et la diffusion de nos auteurs de I 856 à I93 I.' Les cahiers de bibliologie I (1980): 3-24.

Gallichan, Gilles. 'L'édition gouvernementale au Québec depuis le xvııIe siècle.' In L'imprimé au Québec: aspects historiques (18e-20e siècles), 269-287. Quebec: Institut québécois de recherche sur la culture, I983.

Gauvin, Daniel. 'Americana and Canadiana: Philéas Gagnon's 
Extremely Rare Catalogue (no. 8, I 887).' The Journal of Rare Old Books I (I984): I5-32.

Gray, John Morgan. Fun Tomorrow: Learning to Be a Publisher and Much Else. Toronto: Macmillan of Canada, r978. $347 \mathrm{p}$.

Guay, Jean-Pierre. Lorsque notre littérature était jeune. Propos de Pierre Tisseyre, recueillis et présenté par Jean-Pierre Guay. Montreal: Pierre Tisseyre, I983. $264 \mathrm{p}$.

Gundy, H. Pearson. 'The Development of Trade Book Publishing in Canada.' In Ontario. Royal Commission on Book Publishing, Background Papers, I-37. Toronto: Queen's Printer and Publisher, Province of Ontario, I972.

Gundy, H. Pearson. 'Literary Publishing.' In Literary History of Canada: Canadian Literature in English, edited by Carl F. Klinck, vol. I, I 88202. 2d ed. Toronto: University of Toronto Press, I976.

Hare, John. 'Sur les imprimés et la diffusion des idées: le Canada à l'époque de la révolution atlantique (fin xvire-début xixe siècle).' Annales historiques de la Révolution française 3 I 3 (I973): 407-42 I.

Hulse, Elizabeth. A Dictionary of Toronto Printers, Publishers, Booksellers and Allied Trades, 1798-1900. Toronto: Anson-Cartwright Editions, $1982.336 \mathrm{p}$.

Hulse, Elizabeth. 'The Life and Times of William Walter Copp: The Book Trades in Nineteenth-Century Toronto.' In Sticks and Stones: Some Aspects of Canadian Printing History, 69-92. Toronto: Toronto Typographic Association, I980.

Hulse, Elizabeth. 'Sources for the Study of the Book Trades in Nineteenth-Century Toronto: Some Notes From A Work in Progress.' Papers of the Bibliographical Society of Canada / Cahiers de la Société bibliographique du Canada i 8 (I979): 39-46.

Janelle, Claude. Les Editions du Jour: une génération d'écrivains. Cahiers du Québec, Collection littéraire. Montreal: Hurtubise HMH, I983. 338 p.

Jensen, Margaret Ann. Love's \$weet Return: The Harlequin Story. Toronto: Women's Educational Press, I984. I88 p.

Kallmann, Helmut. 'Canadian Music Publishing.' Papers of the Bibliographical Society of Canada / Cahiers de la Société bibliographique du Canada I 3 (I974): 40-4I.

Kotin, David. 'Graphic Publishers and the Bibliographer: An Introduction and Checklist.' Papers of the Bibliographical Society of Canada / Cahiers de la Société bibliographique du Canada i 8 (1979): 47-54.

Landon, Richard G., ed. Book Selling and Book Buying: Aspects of the Nineteenth-Century British and North American Book Trade. ACRL Publications in Librarianship, no. 40. Chicago: American Library Association, I978. vii, I 8 p. 
Lemire, Maurice. 'Les relations entre écrivains et éditeurs au Québec au xIxe siècle.' In L'imprimé au Québec: aspects historiques (18e-20e siècles), 207-224. Quebec: Institut québécois de recherche sur la culture, I983.

LeMoine, Réjean. 'Le marché du livre à Québec de I764 à I 839.' Thèse de maîtrise (histoire), Université Laval, I982. 250 p.

Lochhead, Douglas. 'John Ross Robertson, Uncommon Publisher for the Common Reader: His First Years as a Toronto Book Publisher.' Journal of Canadian Studies / Revue d'études Canadiennes I I (1976): I9-26.

Lochhead, Douglas. 'J. Ross Robertson, Publisher: Aspects of the Book Trade in Nineteenth-Century Toronto.' In Book Selling and Book Buying: Aspects of the Nineteenth-Century British and North American Book Trade, edited by Richard G. Landon, 73-86. ACRL Publications in Librarianship, no. 40. Chicago: American Library Association, 1978.

Loomer, L.S. 'Early Children's Books of the Atlantic Provinces: Notes on the Literature to I9 15.' The Occasional: An Occasional Journal for. Nova Scotian Museums 6, nos. 2-3 (I980-8I): 9-13, 23-28.

McLeod, Donald W. 'William Cameron Chewett and W.C. Chewett \& Company of Toronto: Printers and Publishers.' In Papers of the Bibliographical Society of Canada / Cahiers de la Société bibliographique du Canada 2 I (I982): I I-5 I.

Nadeau, Vincent. 'Au commencement était le fascicule: aux sources de l'édition québécoise contemporaine pour la masse.' In L'imprimé au Québec: aspects historiques (18e-20e siècles), 243-253. Quebec: Institut québécois de recherche sur la culture, I983.

Olivier, Daniel. 'Vie et oeuvre d'un grand bibliophile québécois: Philéas Gagnon (I854-I9 I 5).' Les cahiers de livre ancien du Canada français I, no. I (I984): 3-29.

Ontario. Royal Commission on Book Publishing. Background Papers. Toronto: Queen's Printer and Publisher, Province of Ontario, I972.395 p.

Ontario. Royal Commission on Book Publishing. Canadian Publishers et Publishing. Toronto: The Queen's Printer for Ontario, I973. 37 I p.

Parker, George L. The Beginnings of the Book Trade in Canada. Toronto: University of Toronto Press, I985. xxviii, 346 p.

Parker, George L. 'The British American Book Trade in the I840s: The First Crisis.' Papers of the Bibliographical Society of Canada / Cahiers de la Société bibliographique du Canada i 2 (1973): 82-99.

Parker, George L. 'Haliburton and Moodie: The Early Publishing History of The Clockmaker, Ist Series, and Roughing It in the Bush.' In Bibliographical Society of Canada Colloquium III / Société bibliographique du Canada, III[e] colloque, 1978, I 39-I60. Toronto: The Coach House Press, I979. 
Parker, George L. 'A History of a Canadian Publishing House: A Study of the Relation Between Publishing and the Profession of Writing, I890I940.' Ph.D. thesis, University of Toronto, I969. 2 vols. [McClelland \& Stewart]

Perrier, A. 'Etude de l'édition de livres au Québec, I969-I977.' Documentation et bibliothèques 25 (I979): I39-I 50.

Les Presses de l'Université Laval, 1950-1975: 25 ans. Quebec: Les Presses de l'Université Laval, I975. I6 p.

Pullan, Diane. 'Harlequin: A Corporate Romance,' Quill Æ) Quire, 45 (August i979): 8-9.

Robert, Lucie. 'Prolégomènes à une étude sur les transformations du marché du livre au Québec (r900-1940). In L'imprimé au Québec: aspects historiques (18e-20e siècles), 225-242. Quebec: Institut québécois de recherche sur la culture, I983.

Roy, Jean-Louis. Edouard-Raymond Fabre, libraire et patriote canadien, 1799-1854: contre l'isolement et la sujétion. Les Cahiers du Québec, I7. Collection Histoire et documents d'histoire. Montreal: Hurtubise $\mathrm{HMH}$, I974. 220p.

Roy, Jean-Louis. 'La Librairie Crémazie.' In Crémazie et Nelligan: recueil d'études préparé sous la direction de Réjean Robidoux et Paul Wyczynski, I I-42. Montreal: Fides, I98I.

Roy, Jean-Louis. 'Livre et société bas-canadienne: croissance et expansion de la librairie Fabre (I 8 I6-I 855).' Histoire Sociale / Social History 5 (I972): II7-I43.

Roy, Jean-Louis. 'Perrault, Louis, libraire, éditeur-imprimeur.' In Dictionnaire biographique du Canada, vol. 9, 698-699. Quebec: Les Presses de 1'Université Laval, I977. English version: Dictionary of Canadian Biography, vol. 9, 633. Toronto: University of Toronto Press, I976.

Roy, Jean-Louis. 'Une région culturelle mal connue: le pouvoir des libraries ou les librairies du pouvoir.' In L'évolution du rôle social de l'imprimé et de ses agents au Québec. Conférences Aegidius Fauteux, 1979-1980, 23-45. Montreal: Les Conférences Aegidius-Fauteux, I98I.

St. John, Edward Stuart. 'The Graphic Publishers Limited, I925-I932.' Master's thesis, Carleton University, I974.

St. John, Judith. 'Early Canadian Children's Books.' In Bibliographical Society of Canada, Colloquium III / La Société bibliographique du Canada, IIIe colloque, 1978, 82-83. Toronto: The Coach House Press, I979.

Scott, Joel A. 'Publishing in Canada, I75 I-I867.' Amphora I 2 (Fall-Winter I972/I973): I7-24.

Seccombe, W.W. A Private Concern. Willowdale, Ont.: Nelson, Foster \& Scott, I974. vi, 200 p. [Seccombe House] 
Sévigny, Marc. 'L'aventure périlleuse de l'édition pour enfant.' Education Québec 9, no. 6 (1979): I0-I7.

Simard, Sylvain. 'La diffusion du livre canadien en France avant I9 I4.' Etudes canadiennes / Canadian Studies 6 (I979): 75-80.

Sinclair, David. 'The First Pirated Edition of Tennyson's Poems.' The Book Collector 22 (I973): I77-I88. [Publication of Tennyson's poems in Toronto]

Smith, Harold. The Society for the Diffusion of Useful Knowledge, 18261946: A Social and Bibliographical Evaluation. Dalhousie University Library and School of Library Service, Occasional Paper 8. Halifax: Dalhousie University Library and School of Library Service, I974. ii, roop.

Spadoni, Carl. 'Stephen Leacock and the Macmillan Company of Canada.' Papers of the Bibliographical Society of Canada / Cahiers de la Société bibliographique du Canada 22 (1983): 56-80.

Stone, Patricia. 'The Publishing History of W.H. Smith's Canada: Past Present and Future: A Preliminary Investigation.' Papers of the Bibliographical Society of Canada / Cahiers de la Société bibliographique du Canada I9 (I980): 36-68.

Symposium on the Canadian Book, Regina, Saskatchewan, 1972. Books in Canada 1972: Papers Presented at a Symposium on the Canadian Book at the Canadian Library Association Conference, Regina, 13-14 June 1972. Edited by Basil Stuart-Stubbs. Ottawa: Canadian Library Association, I972. vi, $37 \mathrm{p}$.

'Ten Years that Shook the Trade.' Quill e) Quire 45, no. I4 (I979): 6-ro. Thériault, Michel. Le livre religieux au Québec depuis les débuts de l'imprimerie jusqu'à la Confédération, 1764-1867: relevé statistique et essai d'interprétation. [Montreal]: Graduate School of Library Science, McGill University, I 977 . ii, 55 p.

Thériault, Michel. 'Le livre religieux au Québec depuis les débuts de l'imprimerie jusqu'à la Confédération (I 764-I 867): relevé statistique et pistes de recherche.' In Livre, bibliothèque et culture québécoise: mélanges offerts à Edmond Desrochers, s.j., I I 3-I29. Montreal: ASTED, I977.

Thériault, Yvon. Les publications parlementaires d'hier et d'aujourd'hui. Quebec: Assemblée nationale du Québec, I980. 39 p.

Thériault, Yvon. 'Les publications parlementaires d'hier et d'aujourd'hui.' Bulletin de la Bibliothèque de l'Assemblée nationale du Québec I4, no. 3 (r984): 66-7r.

Thériault, Yvon. 'Les publications parlementaires et législatives du Québec de I79I à nos jours.' Bulletin trimestriel de la Bibliothèque de la Législature 4, no. I-2 (I973): 4 I-48. 
Tisseyre, Pierre. 'L'édition au Québec.' In L'évolution du rôle social de l'imprimé et de ses agents au Québec. Conférences Aegidius-Fauteaux, 1979-1980, I-22. Montreal: Conférences Aegidius-Fauteux, I98I.

Turner, A.K. 'Romance of Harlequin Enterprises.' Publishers Weekly 204 (Sept. 3 I973): 3I-32.

Villon, P. 'Rôle joué par les presses universitaires au Québec: historique et réalisations des 4 presses existantes.' Forces 24 (I973): 45-48.

Whiteman, Bruce, comp. 'The Archive of the Macmillan Company of Canada Ltd. Part I, I905-1965.' McMaster University Library Research News 8, no. I (Spring I984): I-97.

Whiteman, Bruce. 'A Canadian Publishing House: Some Notes on the Macmillan Co. of Canada Archive at McMaster University Library, Hamilton, Canada.' Publishing History ro (I98 I): 59-64.

Whiteman, Bruce. 'The Publication of Maria Chapdelaine in English.' Papers of the Bibliographical Society of Canada / Cahiers de la Société bibliographique du Canada 2 I (I982): 52-59.

Wilson, J. Donald. 'Common School Texts in Use in Upper Canada Prior to I845.' Papers of the Bibliographical Society of Canada / Cahiers de la Société bibliographique du Canada 9 (r970): 36-53.

Wood, W.C.H. 'Philéas Gagnon, Bibliophile and Bibliographer.' The Journal of Rare Old Books I (I984): I I-I4.

Zilm, Glennis. 'B.C.'s First Books.' Amphora 45 (I98I): r 8-23.

Zilm, Glennis. 'Early B.C. Books: An Overview of Trade Book Publishing in British Columbia in the I880's, with Checklists and Selected Bibliography Related to British Columbiana.' Master's thesis, Simon Fraser University, British Columbia, I981. xi, 303 p.

Fine Printing, Small and Private Presses, Livres d'Artistes

Bibliothèque nationale du Québec. Editions Erta: exposition, mars-avril, 1971. Montreal: Ministère des affaires culturelles, I97 I. 34 p.

Bradbury, Maureen. Fine Printing by Canadian Private Presses: A Descriptive Listing of the Holdings of Special Collections, Part I, Presses Outside Ontario. News from the Rare Book Room, I7. Edmonton: Special Collections, University of Alberta Library, I978. 97 p.

Bradbury, Maureen. Fine Printing by Canadian Private Presses: A Descriptive Listing of the Holdings of Special Collections, Part II, Presses of Ontario. News from the Rare Book Room, I 8. Edmonton: Special Collections, University of Alberta Library, I980. I 55 p.

Bringhurst, Robert, comp. Ocean, Paper, Stone: The Catalogue of an Exhibition of Printed Objects Which Chronicles More Than a Century of Literary Publishing in British Columbia. Vancouver: William Hoffer, I984. I 2 p. 
Canada. National Design Council. The Look of Books / Les plus beaux livres. Ottawa: National Design Council, I974. 39 p.

The Canadian Private Presses in Print: A List of Books ↔ Broadsides, Posters « Pamphlets, Ephemera, etc. Compiled by Lyndsay Dobson Books. Grimsby, Ont.: Lyndsay Dobson Books, I983. 50 p.

Centre culturel Canadien / Canadian Cultural Centre, Paris. Art Global: dix années d'édition d'art. Une exposition organisée par le Centre culturel canadien, Paris. Paris: Le Centre culturel Canadien, I98 I. $26 \mathrm{p}$.

Daignault, Gilles. 'L'aventure d'Art Global.' Vie des arts 24, no. 95 (I979): $25-27$.

Dair, Carl. Design with Type. Toronto: University of Toronto Press, I982. vi, I $62 \mathrm{p}$.

Duciaume, Jean-Marcel. 'Le livre d'artiste au Québec: contribution à une histoire.' Etudes françaises I 8, no. 2 (1982): 90-98.

Ettlinger, John R.T. 'The Dawson Room, a Practical Centre for the Book Arts.' Canadian Library Journal 36, no. I-2 (I979): 43-48.

Gatenby, Greg. 'Reviving the Art of Printing.' Quill « Quire 42, no. I 5 (Nov. I976): I8. [Dreadnaught Press]

Giguère, Roland. 'Une aventure en typographie: des Arts graphiques aux Editions Erta.' Etudes françaises I 8, no. 2 (I982): 99-I04.

Guest, Tim, ed. Books by Artists, by Germano Celant and Tim Guest. Toronto: Art Metropole, I98I. I26, 2 p.

Hould, Claudette. Répertoire des livres d'artistes au Québec, 1900-1980. Avec la collaboration de Sylvie Laramée. Montreal: Bibliothèque nationale du Québec, I982. 240 p.

Inkster, Tim. The Coach House Press. Guelph, Ont.: Alive Press, I 974. 23 p.

Kotin, David B. and Marilyn Rueter, comp. Reader, Lover of Books, Lover of Heaven: A Catalogue Based on an Exhibition of the Book Arts in Ontario. Compiled by David Kotin. With a Checklist of Ontario Private Presses by Marilyn Rueter. Willowdale, Ont.: North York Public Library, I978. Io9 p.

Kotin, David B. and Marilyn Rueter. Reader, Lover of Books: The Book Arts in Ontario, Volume 2, 1981. Willowdale, Ont.: North York Public Library, I981. 79 p.

Leduc, Jean. 'Le livre matériel de poésie au Québec, I950-I970.' Thèse de maîtrise (bibliothéconomie), Université de Montréal, I980. iii, I69 p.

Leduc, Jean. 'Le livre matériel de poésie au Québec de I950 à I970.' Documentation et bibliothèques 28, no. 3 (1982): 105-109.

Literary Press Group Catalogue. Toronto: The Literary Press Group, 1975Annual. [Contains information on the presses]

'Le livre d'artiste.' 10-5155-20 Art contemporain 4 (été I983): 8-3 I. [Plusieurs articles sur le livre d'artiste et le livre objet] 
'Le livre-texte.' Etudes françaises I 8, no. 3 (I983): 3-I29. [Numéro spécial sur le livre]

Lochhead, Douglas. 'Bibliographical Presses.' Scholarly Publishing 2 (I97I): 265-272.

McDonald, Rod. 'Cartier Revisited.' The Devil's Artisan: A Journal of the Printing Arts I 3 (1984): 4-8.

'L'objet-livre.' Etudes françaises I 8, no. 2 (I982): I-I04. [Numéro spécial de la revue Etudes françaises]

Payant, René. 'L'émancipation du livre d'artiste.' Etudes françaises i 8, no. 3 (I983): 9-I 29.

Penner, Jon. 'Suicide: The Economic Insanity of Limited Editions.' Canadian Review I, no. 3 (I974): 8.

Poff, Douglas. 'Carl Dair and the Cartier Type Face.' In Sticks and Stones: Some Aspects of Canadian Printing History, 25-46. Toronto: Toronto Typographic Association, I980.

Roussan, Jacques de. 'Michel Nantel, artisan du livre.' Vie des arts $2 \mathrm{I}$, no. 83 (I976): 59-6I.

Rueter, Marilyn. 'The Private Press in Canada: A Brief Survey.' In Sticks and Stones: Some Aspects of Canadian Printing History, 93-I I 4. Toronto: Toronto Typographic Association, I980.

Rueter, William. Order Touched with Delight: Some Personal Observations on the Nature of the Private Press, with an Account of the Aliquando Press. Toronto: Aliquando Press, I976. 8 p. Sedgwick, D. 'Business Booms for Fine Editions.' Quill «) Quire 45, no. I2 (I979): I9, $2 \mathrm{I}$.

Thompson, V. 'Tribute to the Craft of Bookmaking.' Quill e) Quire 43, no. $5(\mathrm{r} 977): 22$.

Tratt, Grace. Checklist of Canadian Small Presses, English Language. Dalhousie University Library and School of Library Service, Occasional Paper 6. Halifax: Dalhousie University and School of Library Service, I974. I 52 p. 